\title{
Evaluation of energy efficiency of the long distance energy transport systems for renewable energy
}

\author{
S.P.Popov ${ }^{1}$, O.A. Baldynov ${ }^{1}$ \\ ${ }^{1}$ Melentiev Energy Systems Institute Siberian Branch of the Russian Academy of Sciences Irkutsk, Russian Federation
}

\begin{abstract}
This article describes the systems of long-distance transport of energy from renewable energy sources. A comparative analysis of the energy efficiency of energy complexes in the transport of energy analysis is performed carriers such as electricity and hydrogen in a liquefied and chemically bound state.
\end{abstract}

Key words: renewable energy, efficiency of energy complexes, energy transport, hydrogen energy, direct current lines,

\section{Introduction}

According to energy forecasts, the share of primary energy consumption from renewable sources will significantly increase in the future [1]. The potential for the use of renewable energy sources (RES) increases under certain climatic conditions allowing to raise the efficiency of production of energy: strong winds at the sea shores of The Arctic and Pacific oceans, the solar radiation - in the arid areas of Australia and East Asia.

Centers of energy consumption can be located at a considerable distance from the territories where renewable energy can be produced with greater efficiency. As a result import of renewable energy may become possible; this raises the question of organizing its long-distance transport.

Solar photovoltaic (SPP) and wind stations (WPP) are the most widely spread among renewable energy generators, those technologies for the production of electricity have been successfully commercialized in recent years. The organization of energy transport infrastructure requires significant investment and depends on many factors: the achievements of scientific and technical progress in the field of materials science and equipment, industry capacities, the availability of the necessary manpower. However, today there are projects of the energy transmission over 1,000 km distance (see Table 1) [2-9].

Table 1 Long-distance energy transport projects

\begin{tabular}{|l|l|c|c|}
\hline Country & \multicolumn{1}{|c|}{ Project } & $\begin{array}{c}\text { Distance, } \\
\mathrm{km}\end{array}$ & $\begin{array}{c}\text { Commis- } \\
\text { sioning }\end{array}$ \\
\hline Brazil & $\begin{array}{l}\text { Rio Madeira HVDC } \\
\text { Classic - from } \\
\text { hydropower plants in the } \\
\text { north-west of Brazil to } \\
\text { São Paulo } \pm \text { ( } 600 \mathrm{kV})\end{array}$ & 2375 & 2014 \\
\hline China & $\begin{array}{l}\text { HVDC from Xinjiang } \\
\text { Uygur Autonomous } \\
\text { Region to Anhui } \\
\text { Province }( \pm 1100 \mathrm{kV})\end{array}$ & 3293 & 2019 \\
\hline
\end{tabular}

\begin{tabular}{|c|c|c|c|}
\hline $\begin{array}{l}\text { Egypt, } \\
\text { Cyprus, } \\
\text { Greece }\end{array}$ & $\begin{array}{l}\text { EuroAfrica } \\
\text { Interconnector } \\
\text { underwater DC } \\
\text { network energy } \\
\text { Egypt and Greece } \\
\text { currently being designed. }\end{array}$ & 1707 & 2021 \\
\hline $\begin{array}{l}\text { Israel, } \\
\text { Cyprus, } \\
\text { Greece }\end{array}$ & $\begin{array}{l}\text { EuroAsia Interconnector } \\
-\mathrm{DC} \text { underwater energy } \\
\text { network connecting } \\
\text { Israel and Cyprus and } \\
\text { then Greece currently } \\
\text { being designed. }\end{array}$ & 1518 & 2023 \\
\hline Brazil & $\begin{array}{l}\text { An ethanol pipeline } \\
\text { connecting ethanol plants } \\
\text { in the state of Mato } \\
\text { Grosso and Rio de } \\
\text { Zeneiro currently being } \\
\text { designed. }\end{array}$ & 2000 & no data \\
\hline Japan & $\begin{array}{l}\text { Hydrogen Spera }- \text { a } \\
\text { project on the marine } \\
\text { transport of hydrogen- } \\
\text { containing substances } \\
\text { (methylcyclohexane), } \\
\text { which will ensure the } \\
\text { supply of hydrogen from } \\
\text { Australia to Japan. }\end{array}$ & 7000 & 2020 \\
\hline
\end{tabular}

Various options for the transport of energy from renewable energy sources are presented in these projects and the question that arises is of the comparative energy efficiency of such systems and

their competitive advantages. Let us consider the means for long distance transportation systems to deliver renewable energy to consumers.

\section{A review of transport technologies}

The transportation of electricity from renewable energy sources to consumers is based on the construction of high-voltage direct current lines (HVDC). This technology ensures the transmission of electrical energy over long distances with minimal losses. An alternative method of transportation of energy from RES is based on the concept of synthetic fuel production «Power to Gas» $(\mathrm{P} 2 \mathrm{G})$. The starting point 
for $\mathrm{P} 2 \mathrm{G}$ is the use of excessive electrical energy to produce hydrogen as an energy carrier. At the first stage, electricity being generated by RES is consumed by electrolyzers that produce hydrogen. Further, there are several possible technologies available:

- transport and direct use of hydrogen as an energy carrier,

- production of liquid organic hydrogen carriers (LOHC) with their subsequent transport and dehydrogenation (release) of hydrogen at consumer side,

- production of other energy carriers based on hydrogen, like synthetic methane, ammonia, etc.

Hydrogen can be transported in the gaseous or liquefied state by traditional means of transport - by road, rail, sea, as well as through pipelines. The physicchemical properties of hydrogen present challenging technical requirements for the systems of its use, storage and transport hydrogen. In this regard, the construction of the trunk hydrogen pipelines is inefficient, since expensive materials are required for the internal anti-corrosion coating. The transport of hydrogen through the pipeline costs 1,5 more than the transport of natural gas [10].

There are two ways to reduce the impact of hydrogen on the elements of storage and transport systems:

1) the use of a gas mixture of natural gas and hydrogen. Hydrogen blending of $5-15 \%$ is allowed for pipeline transportation [11]. The ratio of gases may vary depending on the material of the pipeline and gas equipment. The risks are minor with technological control in place and compliance with the permissible content of hydrogen both for the network of pipelines, and for end users. The use of a gas mixture can be considered as a method of gradual transition to hydrogen energy.

2) the use of substances-carriers that contain hydrogen in the chemical composition. Such substances came to be known as Liquid Organic Hydrogen Carrier (LOHC).

LOHC includes, in particular, methylcyclohexane $(\mathrm{MCH})$, an organic substance obtained through the hydrogenation of toluene. Hydrogen in the $\mathrm{MCH}$ composition can be safely stored and transported in a liquid state at ambient temperature and pressure.

Hydrogenation of toluene (the process produce $\mathrm{MCH}$ ) and the reverse process of hydrogen product occur without the consumption of toluene. After dehydration on the consumer's side, toluene is transported back to recycle the production of $\mathrm{MCH}$. The process of methylcyclohexane dehydrogenation is endothermic and occurs at high energy costs that reduce the efficiency of the whole chain. Chiyoda Corporation was able to increase the efficiency of the $\mathrm{MCH}$ production process to $99 \%$ and the dehydrogenation process to $98 \%$ during the demonstration tests in 2018 [12].

In accordance with the UN Recommendations on the transport of dangerous goods, methylcyclohexane is classified as a highly flammable liquid, its hazard category is the same as that of gasoline and diesel, $\mathrm{MCH}$ belongs to the 3rd hazard class of chemicals (Low Hazard Substances) [14]. The use of MCH has a high technological capacity for the storage and transport of hydrogen over long distances, its use allows to exclude the damaging effect of hydrogen on metals. MCH practically doesn't evaporate.

The existing petroleum infrastructure can be used for the $\mathrm{MCH}$. In the case of large volumes of transport of hydrogen, the most suitable way of delivery for both hydrogen and $\mathrm{MCH}$ will be tanker transportation. Transmission of the $\mathrm{MCH}$ requires two branches: direct - for the transfer of $\mathrm{MCH}$ and the reverse - for the transfer of toluene [11].

Ammonia is also classified as LOHC. Ammonia contains in its composition more hydrogen on the volumetric weight in contrast to the $\mathrm{MCH}$. Moreover ammonia can be used in energy industry as a fuel at ammonia fuel cells and steam-gas station. However, during ammonia combustion hazardous emissions are generated.

Ammonia must be stored and transported under a pressure of $0.87 \mathrm{MPa}$ that leads to additional energy losses [13]. A temperature of at least $400^{\circ} \mathrm{C}$ is demanded to dehydrate ammonia. The temperature of methylcyclohexane dehydrogenation is 3-4 times lower. Ammonia technologies are presented in Table 2. $[13,14,15,16]$.

Table 2 Comparative characteristics of methylcyclohexane

\begin{tabular}{|l|c|c|}
\hline \multicolumn{1}{|c|}{ Indicators } & $\mathrm{MCH}$ & Ammonia \\
\hline $\begin{array}{l}\text { Hydrogenation } \\
\text { temperature }\left({ }^{\circ} \mathrm{C}\right)\end{array}$ & $200-400$ & $350-900$ \\
\hline $\begin{array}{l}\text { Dehydration } \\
\text { temperature }\left({ }^{\circ} \mathrm{C}\right)\end{array}$ & $100-200$ & $400-600$ \\
\hline $\mathrm{H}_{2}$ density $(\mathrm{wt} \%)$ & $6,16 \%$ & $17,8 \%$ \\
\hline Storage losses & $<0,14 \% /$ year & $0,14 \% /$ year \\
\hline
\end{tabular}

Another option for the transport of renewable energy is production of synthetic methane (SM). Is allows to introduce the renewable energy into the existing gas system without any restrictions, and avoid intermittency and energy storage issues. The cost of SM is higher than the cost of natural gas, however, its use may be preferable to natural gas with a tax burden on greenhouse gases emission; where exists a necessity to reduce dependence on energy-exporting countries and a number of other similar conditions. While the process of SM production by reacting hydrogen with carbon dioxide under pressure is energy-intensive, with high energy losses, and therefore this method of energy transport is not considered in this paper.

\section{A review of hydrogen consumption technologies}

The use of hydrogen to satisfy energy services is possible for all groups of consumers: buildings, 
transport, and industry. In addition, with hydrogen produced it is possible to get not only electric power, but also heat energy. The efficiency of electricity generation on fuel cells ranges from $30 \%$ to $55 \%$; the total efficiency can be increased through the use of heat energy (see Table 3 ). The high efficiency indicator of hydrogen is demonstrated by the project "Ene-farm" for small power consumers in Japan. A solid-oxide fuel cell (with a capacity of 200 to $700 \mathrm{~W}$, depending on the model) ensures the production of electrical and heat energy, the efficiency of its combined cycle reaches 87 percent [18].

Table 3Comparative characteristics of fuel cells

\begin{tabular}{|l|c|c|c|c|}
\hline \multicolumn{1}{|c|}{$\begin{array}{c}\text { Fuel cell } \\
\text { type }\end{array}$} & $\begin{array}{c}\text { Operating } \\
\text { temperature }\end{array}$ & $\begin{array}{c}\text { Electric } \\
\text { power } \\
\text { generation } \\
\text { efficiency }\end{array}$ & $\begin{array}{c}\text { Combined } \\
\text { cycle } \\
\text { efficiency }\end{array}$ & Capacity \\
\hline $\begin{array}{l}\text { Proton- } \\
\text { exchange } \\
\text { membrane } \\
\text { (PEMFC) }\end{array}$ & $60-160^{\circ} \mathrm{C}$ & $30-35 \%$ & $50-70 \%$ & $0,1 \mathrm{~kW}$ \\
\hline $\begin{array}{l}\text { Phosphoric } \\
\text { acid } \\
\text { (PAFC) }\end{array}$ & $150-$ & $35 \%$ & $70-80 \%$ & $11 \mathrm{MW}$ \\
\hline $\begin{array}{l}\text { Molten } \\
\text { carbonate } \\
\text { (MCFC) }\end{array}$ & $700-$ & $45-50 \%$ & $70-80 \%$ & $\begin{array}{c}3-60 \\
\mathrm{MW}\end{array}$ \\
\hline $\begin{array}{l}\text { Solid } \\
\text { oxide } \\
\text { (SOFC) }\end{array}$ & $800-$ & $45-60 \%$ & $70-90 \%$ & $\begin{array}{c}1-100 \\
\mathrm{MW}\end{array}$ \\
\hline
\end{tabular}

The use of fuel cells is also possible for major consumers. In particular, solid-state oxide fuel cells

Energy supply to consumers with the help of hydrogen can be realized not only through fuel cells. Mitsubishi Hitachi Power Systems is developing gas turbine and steam-gas systems. Currently, the company has created several gas turbine plants operating on a gas mixture $\left(20 \% \mathrm{H}_{2} / 80 \% \mathrm{CH}_{4}\right.$ and $30 \% \mathrm{H}_{2} / 70 \%$ $\mathrm{CH}_{4}$ ); their use allows to reduce $\mathrm{CO}_{2}$ emissions level and provides natural gas economy. The company's goal is to create pure hydrogen combine cycle turbine system with efficiency not less than 65 percent [20].

Energy Efficiency Review Assessment of energy efficiency of long-distance energy transport systems of renewable energy is carried out on the basis of a comparison of the elements of the transport system and the efficiency of use by end-consumers. The purpose of this paper is to compare the total losses of longdistance energy transport systems (over 1,000 km) from WPP and SES to the end consumer.

One of the most important quantitative indicators of energy efficiency is the amount of losses. For comparison of transmission systems the problem of energy transport in the amount of 10 million tons of fuel equivalent at a distance from $1,000 \mathrm{~km}$ to 7,000 $\mathrm{km}$ is considered. Three long-distance transport systems are considered: $800 \mathrm{~kW}$ HVDC power line, liquefied hydrogen and methylcyclohexane transport. Corresponding transport chains are shown in Fig. 1.

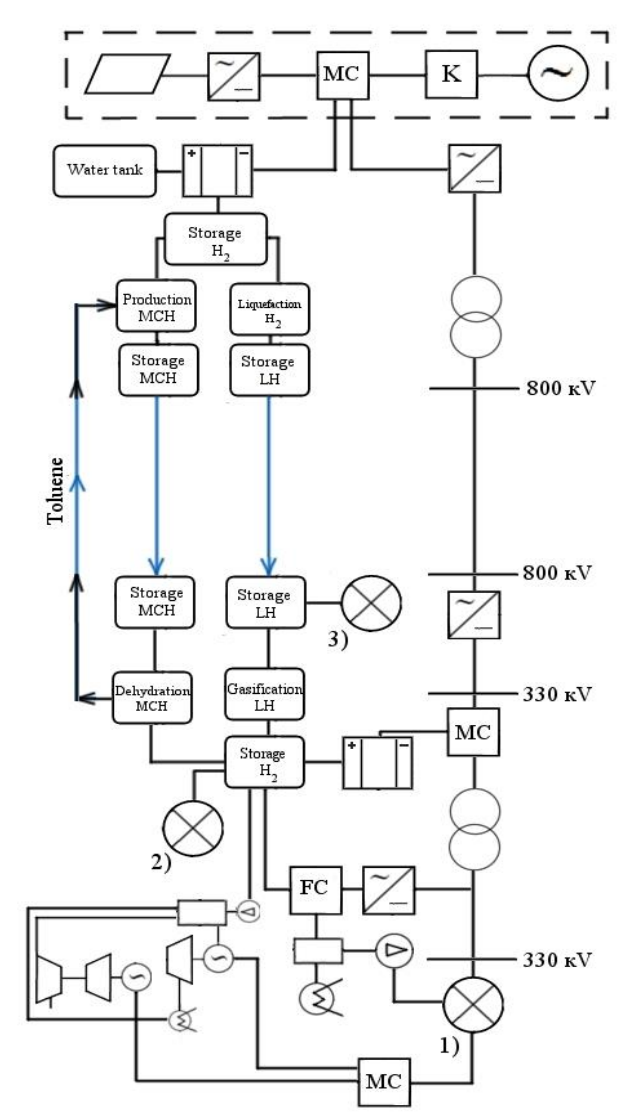

Fig. 1. Long distance energy transportation system

Let us consider an electric power facility based on the transport of energy through DC lines. The electricity generated by solar cells and/or wind generators is transmitted to the control center MC that carries out the switching of current to the HVDC terminal or to the electrolysis plant for the production of hydrogen. At the receiving terminal of the DC power lines, electricity is supplied to industrial consumers (1 at Fig. 2), for transport (2 and 3 at Fig. 2) and for buildings (2 at Fig. 2).

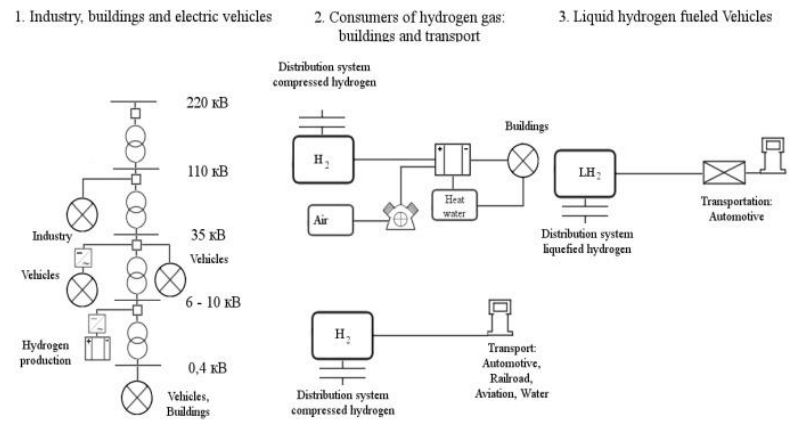

Fig. 2. Distribution network

The energy losses in case of electric power infrastructure is presented in Table 4. Data on losses in distribution lines, shown in Table 4, are average values for the Russian Federation. The level of losses in distribution lines and the efficiency of electrical equipment can differ significantly a particular country [23]. 
Table 4Losses in equipment of the electric power facility

\begin{tabular}{|c|c|c|c|}
\hline Object & $\begin{array}{c}\text { Losses, } \\
\text { percent }\end{array}$ & Object & $\begin{array}{c}\text { Losses, } \\
\text { percent }\end{array}$ \\
\hline $\begin{array}{c}\text { HVDC } \pm 800 \\
\text { кB }\end{array}$ & $\begin{array}{c}3 \text { per } \\
1000 \mathrm{~km}\end{array}$ & Inverter & $2-3$ \\
\hline Main lines & $5-10$ & $\begin{array}{c}\text { Monitoring } \\
\text { center }\end{array}$ & 0,95 \\
\hline $\begin{array}{c}\text { Distribution } \\
\text { network }\end{array}$ & $7-10$ & $\begin{array}{c}\text { Step-down } \\
\text { transformer }\end{array}$ & 2 \\
\hline
\end{tabular}

Hydrogen models of RESs energy transportation. The electricity generated at the SPP and WPP is supplied to electrolysis stations for the production of gaseous hydrogen. The next step is the hydrogen's liquefaction at a temperature of $-250^{\circ} \mathrm{C}$. The energy intensity of this process in various researches ranges from $15 \%$ to $45 \%$ of the output hydrogen energy [ 10 , 22]. Hydrogen liquefaction increases its density (from $0.09 \mathrm{~kg} / \mathrm{m}^{3}$ to $70 \mathrm{~kg} / \mathrm{m}^{3}$ ), thus the volume of hydrogen to be stored is significantly reduced. Special standards of control for liquefied hydrogen are required during its storage and transportation, which affects the final cost of fuel. Currently, only a few models for utilize liquefied hydrogen as a fuel for fuel cell vehicle. The remaining consumer groups use compressed hydrogen. Gasification becomes a necessary stage, and as a result of this process additional losses arise. Losses during storage and transportation, in contrast to power transmission lines, do not depend on distance, but on time: $0.02 \%-0.03 \%$ per day for liquefied and $0.5-1 \%$ per day for gaseous hydrogen [17]. Calculating the efficiency, the time from the moment of production of hydrogen to its consumption must be taken into account. The storage time of hydrogen gas is taken from the conditions of safe use in 1 day. Transport losses are estimated based on the range of losses (see Table 5).

Table 5 Losses in marine transportation of liquefied hydrogen

\begin{tabular}{|l|c|l|c|}
\hline \multicolumn{1}{|c|}{ Process } & $\begin{array}{c}\text { Losses, } \\
\text { percent }\end{array}$ & \multicolumn{1}{|c|}{ Process } & $\begin{array}{c}\text { Losses, } \\
\text { percent }\end{array}$ \\
\hline Electrolyzer & $10-20$ & $\begin{array}{l}\text { Gasification } \\
\text { of liquefied } \\
\text { hydrogen }\end{array}$ & 9 \\
\hline $\begin{array}{l}\text { Hydrogen } \\
\text { storage }\end{array}$ & $\begin{array}{l}0,5-1 \\
\text { (per day) }\end{array}$ & $\begin{array}{l}\text { FC Electric } \\
\text { power } \\
\text { generation }\end{array}$ & $40-60$ \\
\hline $\begin{array}{l}\text { Hydrogen } \\
\text { liquefaction }\end{array}$ & $15-45$ & $\begin{array}{l}\text { FC } \\
\text { Combined } \\
\text { cycle }\end{array}$ & $10-30$ \\
\hline $\begin{array}{l}\text { Storage of } \\
\text { liquefied } \\
\text { hydrogen }\end{array}$ & $\begin{array}{c}0,02- \\
0,03 \text { (per } \\
\text { day) }\end{array}$ & $\begin{array}{l}\text { Hydrogen } \\
\text { combined } \\
\text { cycle gas } \\
\text { turbine }\end{array}$ & 35 \\
\hline
\end{tabular}

Hydrogen can be transported as part of methylcyclohexane. Losses during transport and storage of $\mathrm{MCH}$ are minimal; as a result, the storage of hydrogen in the $\mathrm{MCH}$ composition is less dependent on time (see Table 6).

Table 6 Losses in methylcyclohexane marine transport

\begin{tabular}{|l|c|l|c|}
\hline \multicolumn{1}{|c|}{ Process } & $\begin{array}{c}\text { Losses, } \\
\text { percent }\end{array}$ & \multicolumn{1}{|c|}{ Process } & $\begin{array}{c}\text { Losses, } \\
\text { percent }\end{array}$ \\
\hline Production () & $1-5 \%$ & $\begin{array}{l}\text { Toluene } \\
\text { hydrogenation }\end{array}$ & $30 \%$ \\
\hline Storage & $\begin{array}{c}<0.14 \\
\% / \text { year }\end{array}$ & $\begin{array}{l}\text { Power } \\
\text { generation } \\
\text { (fuel cell) }\end{array}$ & $\begin{array}{c}40- \\
60 \%\end{array}$ \\
\hline Transportation & $\begin{array}{c}<0.14 \\
\% / \text { year }\end{array}$ & $\begin{array}{l}\text { MCH } \\
\text { dehydration }\end{array}$ & $\begin{array}{c}2- \\
30 \%\end{array}$ \\
\hline
\end{tabular}

Conclusions Figure 3 shows a graph of the minimum energy losses of renewable energy HVDC lines, transport of liquefied hydrogen and $\mathrm{MCH}$.

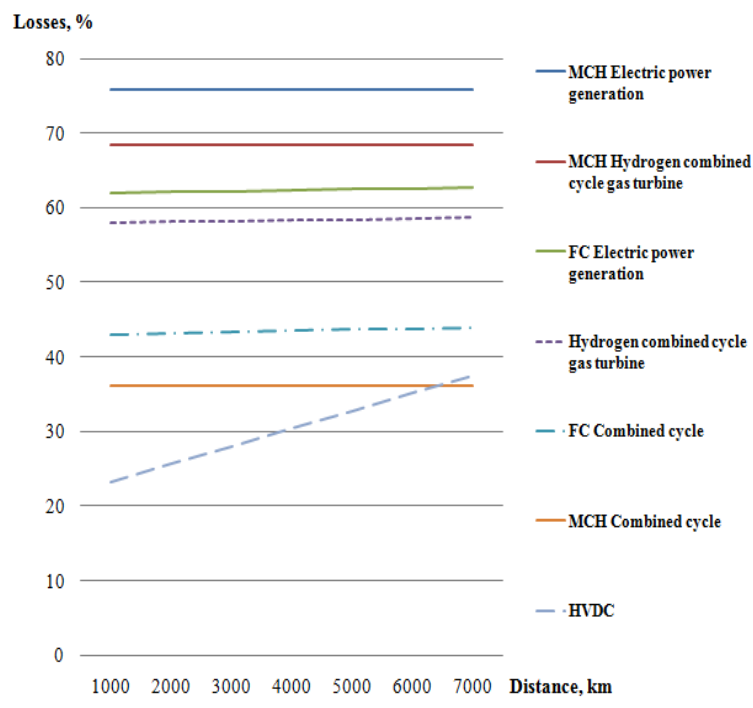

Fig.3 Evaluation of energy efficiency for the long distance NRE energy transportation modes

Minimal losses in energy transport are achieved with the use of direct current lines (from $23 \%$ to $37.5 \%$ ). The maximum losses arise during transmission in distribution networks. In calculating the losses of electric power transport, restrictions on the maximum permissible load of the receiving network were not taken into account.

The most effective method of hydrogen transportation hydrogen is the use of methylcyclohexane. The total losses reach $36.2 \%$ after cogeneration fuel cells. In addition, due to the low level of losses and the wide temperature range, the $\mathrm{MCH}$ is suitable for long-term seasonal storage of electricity.

The total losses in the transport of liquefied hydrogen are higher than in the transport of $\mathrm{MCH}$ (from $43 \%$ to $44 \%$ ). Significant energy losses of hydrogen occur during the transition from a gaseous state to a liquefied one. An established system of distribution and storage of hydrogen which is minimizing losses is essential. Otherwise, the losses of hydrogen during storage can significantly reduce the overall efficiency of the entire transport system. 
As can be seen in fig. 3, losses in electric power transport are less than in the transport of hydrogen and $\mathrm{MCH}$. The transport of renewable energy in the form of $\mathrm{MCH}$ becomes more energy-efficient than using transmission lines DC starting from a distance of 6,000 $\mathrm{km}$. Currently, hydrogen technologies are in the stage of demonstration projects, probably the energy efficiency of hydrogen transport will be higher in the further development. As noted, the energy efficiency of RES with curtailments were not taken into account. In practice, this relates to additional losses in dispatching and transmission of electricity. The transport of hydrogen or $\mathrm{MCH}$ does not have such limitations, since the use of appropriate technologies implies long-term storage of energy carriers and consumption at the appropriate moment.

Energy efficiency is an important indicator in assessing transport systems; the choice of the optimal method should be based on multiple criteria. It is necessary to take into account technical, economic and environmental aspects. Depending on the distance and other factors, a combined energy transport system of RES can be a more efficient way: electric transport (via DC main lines) and storage on the consumer side in the form of $\mathrm{MCH}$ and subsequent dehydration. Such a system will be less dependent intermittent generation of renewable energy sources; will allow accumulating energy, reducing the requirements for carrying capacity of the main transmission lines DC. A comprehensive assessment of the long-range transport of energy from renewable energy sources should be further explored.

\section{References}

1. World Energy Insights Brief: Global energy scenarios comparison review 2019, aavailable at: https://new.abb.com/news/detail/2718/ABB-achievesbreakthrough-with-worlds-most-powerful-hvdctransformer (accessed 1.04.2019)

2. ABB achieves breakthrough with world's most powerful HVDC transformer, aavailable at: https://new.abb.com/news/detail/2718/ABB-achievesbreakthrough-with-worlds-most-powerful-hvdctransformer (accessed 1.04.2019)

3. World's Biggest Ultra-High Voltage Line Powers Up Across China, available at: https://www.bloomberg.com/news/articles/2019-0427/india-slips-further-behind-china-during-first-fiveyears-of-modi (accessed 1.04.2019)

4. Brazil ethanol pipeline owner eyes corn-based fuel makers, available at:

https://www.reuters.com/article/us-brazil-ethanolpipeline/brazil-ethanol-pipeline-owner-eyes-cornbased-fuel-makers-idUSKCN1PA260 (accessed 1.04.2019)

5. Rio Madeira The longest transmission link in the world - 2,375 kilometers, available at: https://new.abb.com/systems/hvdc/references/riomadeira (accessed 1.04.2019)
6. EuroAsia at a glance available at: https://www.euroasia-interconnector.com/about-us/ (дата обращения 1.04.2019)

7. EuroAfrica at a glance, available at: https://www.euroafrica-interconnector.com/ (accessed 1.04.2019)

8. What is "SPERA HYDROGEN" system?, available at: - https://www.chiyodacorp.com/en/service/sperahydrogen/innovations/ (accessed 1.04.2019)

9. Akito Ozawa, Mai Inoue, Naomi Kitagawa, Ryoji Muramatsu, Yurie Anzai, Yutaka Genchi and Yuki Kudoh Assessing Uncertainties of Well-To-Tank Greenhouse Gas Emissions from Hydrogen Supply Chains available at: https://pdfs.semanticscholar.org/8382/8ba5b0358960b5 b5630cea1822031138189d.pdf (accessed 1.04.2019)

10. Hanane Dagdougui, Roberto Sacile, Chiara Bersani, Ahmed Ouammi Hydrogen Storage and Distribution: Implementation Scenarios Production, Storage, Distribution and Safety. - 2018. стр. 37-52

11. M. W. Melaina, O. Antonia, and M. Penev Blending hydrogen into natural gas pipeline networks: a review of key issues. -2013 .

12. About demonstration test result by demo plant available at: - https://www.chiyodacorp.com/jp/service/ spera-hydrogen/demo-plant/ (accessed 1.04.2019)

13. UN Recommendations on the Transport of Dangerous Goods - Model Regulations Eighteenth revised edition available at: https://www.unece.org/trans/danger/publi/unrec/rev18/ 18files_e.html (accessed 1.04.2019)

14. Agung Tri Wijayanta, Takuya Oda, Chandra Wahyu Purnomo, Takao Kashiwagi, Muhammad Aziz. Liquid hydrogen, methylcyclohexane, and ammonia as potential hydrogen storage: Comparison review available at: https://www.sciencedirect.com/science/article/pii/S036 0319919315411 (accessed 1.04.2019)

15. AValera-Medina, H Xiao, MOwen-Jones, W.I.F.David, P.J.Bowen Ammonia for power Author links open overlay panel Progress in Energy and Combustion Science Volume 69. - 2018. стр. 63-102 16. Order of the Ministry of Industry and Energy of the Russian Federation of September 24, 2007 N 406 On approval of the norms of natural loss during storage (draining, filling) of chemical products

17. Muhammad Aziz Production, transportation, and utilization of carbon-free hydrogen, available at: https://www.researchgate.net/publication/327820008 P roduction transportation and utilization_of carbonfree hydrogen (accessed 1.04.2019)

18. Achievement of Accumulated Sales of 100,000 Units of «ENE-FARM» Household full cell system, available

at: https://www.osakagas.co.jp/en/whatsnew/ icsFiles/afi eldfile/2019/03/20/190313.pdf (accessed 1.04.2019)

19.31. M.M. Brodach, N.V. Shilkin. The Use of Fuel Cells for Powering Buildings. Journal Ventilation, heating, air conditioning, heat supply and building heat physics. -2004 . 
20. Paul E.Dodds, Iain Staffell, Adam D.Hawkes, Francis Li, Philipp Grünewal, Will McDowall, Paul Ekins Hydrogen and fuel cell technologies for heating: A review International Journal of Hydrogen Energy Volume 40. - 2015. Стр. 2065-2083

21. The main advantages of SOFC, available at: http://sofc.info/ (accessed 1.04.2019)

22. All eyes are on Hydrogen Energy available at: https://www.mhps.com/special/hydrogen/article_2/inde x.html (accessed 1.04.2019)
23. Information on electricity losses in the networks in absolute and relative terms by voltage levels available at: http://lenenergo.ru/standart/4004.html (accessed 1.04.2019)

24. Bent Sørensen Giuseppe Spazzafumo Hydrogen and Fuel Cells (Third Edition) Emerging Technologies and Applications 3rd Edition. - 2018. Стр. 522 